\title{
Pakistan weighs up impact of sanctions...
}

[LONDON] Pakistan's scientists are bracing themselves for further restrictions on their access to science and technology facilities in Western countries following their government's decision to carry out nuclear tests last week.

But some believe that such restrictions could benefit science in Pakistan by catalysing collaboration between Muslim countries. That is the view of Atta-urRahman, a Pakistani chemist who is coordinator general of Comstech, the Islamabadbased agency responsible for scientific cooperation between the 50-member Organization of Islamic Countries (OIC).

Pakistan is already prohibited from acquiring defence-related technologies from the United Kingdom and the United States. Further restrictions are widely believed to be imminent following the testing of six nuclear devices last week.

One target could be the Abdus Salam International Centre for Theoretical Physics in Trieste, Italy. The centre is a United Nations organization controlled by the International Atomic Energy Agency (IAEA). It was set up by Pakistan's Nobel prize-winning physicist Abdus Salam to enable scientists from developing countries to collaborate with colleagues from the developed world.

Miguel Virasoro, the centre's director, says he expects an "intelligent reaction" possibly in the shape of restrictions to some of the centre's programmes related to nuclear energy. But he says it is unlikely that Indian and Pakistani physicists will be com- pletely isolated. Most of the centre's programmes are "simply basic research" in areas such as high-energy and condensed matter physics, "not nuclear physics", says Virasoro. "However, if the IAEA decides to take action against Pakistan's scientists, we will have to follow that policy" he adds.

Existing technology restrictions on Pakistan include curbs on importing equipment - such as supercomputers - and prohibitions on students doing research in areas such as nuclear physics and lasers.

In contrast to the reaction in the West, Pakistan's nuclear tests have generated overwhelming popular support in Muslim countries. Muslim governments have not come out in support for the tests. But newspaper articles in much of the Middle East have hailed the emergence of the first Muslim nuclear weapons state.

Many of Pakistan's scientists feel their country should take advantage of its newfound status. "The nuclear tests will certainly raise the image of Pakistan as a leader in the field of science and technology in Muslim countries," says Rahman. "This can certainly strengthen the role of Comstech."

Although Comstech was promised US $\$ 10$ million last year by OIC member states for various projects, it has received less than half that amount. But it was recently awarded \$2.1 million by the Jeddah-based Islamic Development Bank for scholarships for 190 students from the 18 least developed member states to train and do research within the OIC's leading institutions.

\section{...as India sees decline in cooperative work}

[NEW DELHI] Indian scientists fear that the subcontinent's 'tit-for-tat' nuclear tests are likely to set back significantly recent attempts to improve cooperation with colleagues from Pakistan.

The prospect of a 'cold war' between the countries is expected to raise the political pressure on scientists from both sides to reduce contact with each other. One event whose fate hangs in the balance, for example, is a conference for scientists from non-aligned countries that Pakistan had proposed to host this year.

"Only last week we had received a letter from Pakistan offering to host the conference," says K. N. Johry, director of the Centre for
Science and Technology of the Non-Aligned Countries, whose headquarters is in New Delhi. "We do not know if the offer still stands."

Pakistan has been an active member of the centre, which promotes scientific exchanges among its 38 member nations. "Scientists from Pakistan played key roles in meetings on medicinal plants organized by the centre last December, and another on DNA fingerprinting," says Johry.

Another potential casualty is the year-old Indo-Pakistan Friendship Forum, which aims to bring Indian and Pakistani health experts together to tackle common problems such as maternal mortality and hepatitis B.
The project's co-founder, Vulimiri Ramalingaswami, a leading health scientist in the region, says it is "Iying dormant now". But he hopes to revive it "once the nuclear dust settles".

Indira Nath, former foreign secretary of the Indian National Science Academy in New Delhi, says the political fall-out from a potential nuclear arms race will set back scientific exchanges.

The Indian and Pakistani science academies do not have direct exchanges "but we get involved with each other through the Federation of Asian Science Academies," says Valangiman Ramamurthi, secretary of India's science ministry.

K.S. Jayaraman

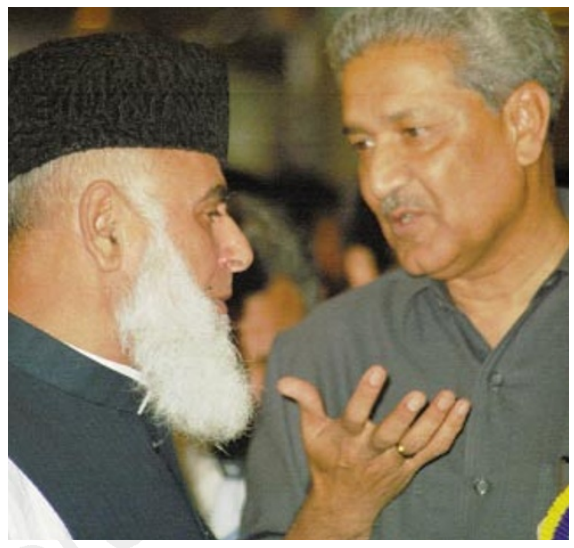

A. Q. Khan (right), founder of Pakistan's nuclear programme, with President Rafiq Tarar.

Abdul Qadeer Khan, founder of Pakistan's nuclear programme and president of the Pakistan Academy of Sciences, is another keen advocate of stronger scientific links between Muslim countries. Khan asks why technological restrictions apply only to certain Muslim states and not other nations. He has in the past supported a call for the setting up of an atomic energy commission for Muslim countries, and stronger links between defence research agencies in the Muslim world.

But such an approach is not without its critics. Iftikhar Ahmed, a Pakistan-born experimental physicist who is president of the Commonwealth Academy of Sciences in London, is deeply critical of the decision to explode nuclear devices, and believes there is little to be gained scientifically by collaborating with Muslim countries.

Ahmed says virtually all of Pakistan's leading scientists were trained, not in Muslim countries, but in Europe or the United States "because that is where the best science is done". He warns that Pakistan is risking its future research base by losing access to Western facilities.

"Before, a fledgling person like me who came from the back galis [alleys] of Lahore could train at the highest levels and work with the best minds," he says. "Now there will be no more Salams. And even no more Qadeer Khans. We have starved our future generations."

Virasoro, too, questions the scientific benefits of closer ties to Muslim countries when most advanced technology is in the developed world. He says nuclear weapons represent "yesterday's technology", which does not need much research, only resources that could be better spent elsewhere.

"Pakistan is deluding itself if it thinks that exploding a bomb turns it into an advanced, high-technology country," he says. "It is folly to think that you are more advanced than Sweden or Norway just because you have the bomb [and they do not]."

EhsanMasood 